\title{
CONTEXTO ESTRUTURAL DA ÁREA DA FOLHA TOPOGRÁFICA GUAPIARA
}

\author{
STRUCTURAL CONTEXT OF THE GUAPIARA TOPOGRAPHIC MAP AREA \\ Otávio Augusto Ruiz Paccola VIEIRA ${ }^{1}$, Antonio Misson GODOY ${ }^{2}$, Peter Cristian \\ HACKSPACHER ${ }^{2}$, Washington Barbosa LEITE JUNIOR ${ }^{2}$ \\ ${ }^{1}$ Programa de Pós-graduação em Geociências e Meio Ambiente, Instituto de Geociências e Ciências Exatas, Univ. Estadual Paulista, \\ Rio Claro, São Paulo, Brasil. otaviovieirageo@gmail.com. \\ ${ }^{2}$ Departamento de Petrologia e Metalogenia, Instituto de Geociências e Ciências Exatas, Univ. Estadual Paulista, Rio Claro, São \\ Paulo, Brasil.mgodoy@rc.unesp.br, phack@rc.unesp.br; wleite@rc.unesp.br

Introdução
Geologia Regional
Quadro Estrutural
Domínio I
Domínio II
Domínio III
Juntas
Falha de Empurrão
Zonas de Cisalhamento Transcorrente
Discussões e Conclusões
Referências

RESUMO - A Folha Topográfica de Guapiara 1: 50.000, localiza-se no extremo sul do estado de São Paulo e compreende a porção norte do Terreno Apiaí, de idade meso- a neoproterozoicas, inserido na faixa centro-sul do Cinturão Ribeira da Província Mantiqueira Central. A região caracteriza-se pelas rochas da sequência metavulcanossedimentar do Supergrupo Açungui, definidas pela Formação Água Clara e os grupos Votuverava e Itaiacoca, além de corpos graníticos do Granito Três Córregos e do Granito Capão Bonito, rochas sedimentares do Grupo Itararé, intrusivas básicas associadas ao Magmatismo Serra Geral e sedimentos quaternários. O quadro estrutural é determinado dominantemente pelo arranjo tectônico neoproterozoico. As rochas apresentam uma evolução estrutural do tipo polifásica, evidenciada pela superposição de eventos de principalmente quatro fases deformacionais $D_{n}, D_{n+1}, D_{n+2} D_{n+3}$. Os dois eventos iniciais são relacionados a uma tectônica de cavalgamento, de direção NE/SW e NW/SE, respectivamente, acompanhado de estruturas geneticamente associadas, tais como falhas de cavalgamentos, dobras e as foliações $S_{n}$ e $S_{n+1}$. Superpondo-se a estas estruturas, ocorrem dois eventos $\mathrm{D}_{\mathrm{n}+2}$ e $\mathrm{D}_{\mathrm{n}+3}$, ligados a fase colisional final e uma tectônica transcorrente/transpressiva. Esse evento é responsável pelo dobramento das estruturas pré-formadas, com plano axial de direção NE/SW e NW/SE, respectivamente.

Palavras-chave: geologia, estrutural, mapeamento, Guapiara.

ABSTRACT - The Guapiara Topographic Map 1:50,000 is located in the southernmost part of the state of São Paulo and comprises the northern portion of the Apiaí Terrain, of meso- to neoproterozoic age, inserted in the central-southern zone of the Ribeira Belt of the Mantiqueira Central Province. The region is characterized by the rocks of the metavolcanic/metasedimentary sequence of the Açungui Supergroup, defined by the Água Clara Formation and the Votuverava and Itaiacoca groups, as well as granite bodies of the Três Córregos Granite and the Capão Bonito Granite, sedimentary rocks of the Itararé Group, basic intrusive associated to the Serra Geral Magmatism and quaternary sediments. The structural framework is dominantly determined by the neoproterozoic tectonic arrangement. The rocks present a structural evolution of the polyphase type, evidenced by the superposition of events of mainly four deformation phases $D_{n}, D_{n+1}, D_{n+2}$ and $D_{n+3}$. The two initial events are related to a tectonic thrust, NE/SW and NW/SE direction, respectively, accompanied by genetically associated structures, such as thrust faults, folds and $S_{n}$ and $S_{n+1}$ foliations. Superimposing to these structures, two events $\mathrm{D}_{\mathrm{n}+2}$ and $\mathrm{D}_{\mathrm{n}+3}$ occur, connected to the final collision phase and a strike-slip/transpressive tectonic. This event is responsible for the folding of the pre-formed structures, with the direction of axial plane being NE/SW and NW/SE, respectively.

Keywords: geology, structural, mapping, Guapiara.

\section{INTRODUÇÃO}

A área da Folha Topográfica de Guapiara (SG-22-X-B-II-2), na escala 1:50.000 do Instituto Brasileiro de Geografia e Estatística, situada entre as coordenadas $48^{\circ} 30^{\prime}$ a $48^{\circ} 45^{\prime} \mathrm{W}$ e $24^{\circ}$ a $24^{\circ} 15^{\prime}$ S, localiza-se na Província Mantiqueira Central, na faixa centro-sul do Cinturão Ribeira, que corresponde a um dos orógenos desenvolvidos durante a Orogenia Neoproterozoica Brasiliano-Pan Africana e, mais especificamente, se localiza na parte norte do Terreno Apiaí.

A região situa-se no extremo sul do estado de São Paulo e é caracterizada por rochas de idade meso- a neoproterozoica da sequência metavulcanossedimentar do Supergrupo Açungui, constituída pelos metassedimentos da Formação Água Clara e dos grupos Votuverava e Itaiacoca.

Associada a expressiva ocorrência areal destas sequências na área, ocorrem rochas granitoides neoproterozoicas do Complexo Granito Três Córregos e do Maciço Granito Capão Bonito, além de rochas fanerozoicas da Bacia Sedimentar do Paraná, sendo reconhecido 
as sedimentares do Grupo Itararé, as intrusivas básicas associadas ao Magmatismo Serra Geral e os sedimentos quaternários.

A região teve nos seus estudos iniciais uma grande ênfase à prospecção mineral, a partir de trabalhos ligados ao Departamento Nacional de Pesquisa Mineral (DNPM), através de mapeamento geológico e de prospecção da Folha Capão Bonito em escala 1: 50.000 e de áreas dos municípios do entorno da folha topográfica, por Chiodi Filho et al. (1983).

Trabalhos específicos na região da folha foram realizados pela Companhia de Pesquisa de Recursos Minerais (CPRM), Superintendência Regional de São Paulo (SUREG), através do Mapa Geológico da Folha Guapiara (SG. 22-XB-II-2) (Takahashi et al., 1984).

A região está delimitada no mapa geológico de integrações do estado de São Paulo em escala 1: 500.000 elaborado pelo Instituto de Pesquisa Tecnológica - IPT (Bistrichi et al., 1981, Almeida et al., 1981) e no mapa em escala 1: 750.000 elaborado pela Companhia de Pesquisa de Recursos Minerais (Perrotta et al., 2005).

Os principais trabalhos regionais apresentam enfoque na identificação e descrição das diversas sequências de rochas metassedimentares separadas por zonas de cisalhamento (Soares, 1987, 1988; Campanha et al., 1987; Campanha, 1991; Basei et al., 1992; Reis Neto, 1994; Siga Junior, 1995; Fassbinder, 1996; Campanha \& Sadowski, 1999). As relações petrológicas e estratigráficas da área da Folha Guapiara foram mais intensamente discutidas nos trabalhos de Vieira (2017) e Vieira et al. (2018).

A evolução geológica do Domínio Apiaí e da região de Guapiara, parte da compreensão do contexto estrutural, a partir do estudo dos lineamentos macroestruturais, que foram abor- dados por Soares $(1987,1988)$, Campanha et al. (1987), Fiori (1990, 1992), Campanha (1991, 2002), Basei et al. (1992), Basei et al. (2003), Reis Neto (1994), Siga Junior (1995), Fassbinder (1996), Campanha \& Sadowski (1999), Hackspacher \& Godoy (1999), Faleiros (2008) e Faleiros et al. (2010, 2011).

Os aspectos estruturais da região de Guapiara reconhece-se muitas vezes uma superposição de lineamentos mesozoicos, orientados na direção NW-SE, marcando importantes feições morfoestruturais regionais, que são resultantes da estruturação do Arco de Ponta Grossa que representa uma estrutura tectônica de soerguimento com eixo orientado a NW. A estes lineamentos encontram-se associados expressivos enxames de diques e são denominados por Lineamento Guapiara, Lineamento São Jerônimo-Curiúva, Lineamento Rio Alonzo e Lineamento Rio Piquiri (Spinelli \& Gomes, 2008).O estudo dos lineamentos e das feições estruturais (foliações e lineações) locais e em detalhe, é de extrema importância, mas encontra-se muitas vezes dificultada em algumas áreas da região, devido ao difícil acesso razão das coberturas vegetais preservadas do Parque Estadual de Jacupiranga, no Planalto do Alto Turvo.

O propósito deste trabalho é apresentar os dados resultantes da investigação estrutural da área geográfica da Folha Topográfica de Guapiara (Figura 1), dividindo a área em domínios estruturais específicos, baseados nas suas características estruturais e microestruturais e de sua evolução petrológica magmáticametamórfica, com ênfase na caracterização da evolução estrutural e sua relação com a evolução do Terreno Apiaí e o embasamento gnáissico.

\section{GEOLOGIA REGIONAL}

A área insere-se na Província Mantiqueira na definição de Almeida (1967) e Hasui \& Oliveira (1984), na região sul do Cinturão de Dobramentos Sudeste.

A Província Mantiqueira foi subdivida inicialmente por Almeida et al. $(1977,1981)$ em três grandes setores, referidos como Setentrional, Central e Meridional. Essa classificação passou a ser referida como correspondente a três cinturões orogênicos respectivamente: Araçuaí, Ribeira e Tijucas por Hasui et al. (1978) e Hasui (2010).
O Cinturão Ribeira, definido por Almeida et al. (1967), compreende um largo segmento crustal paralelo à linha costeira do sudeste brasileiro, tendo sido amalgamado, deformado e metamorfizado durante a Orogenia BrasilianoPan-Africana (Neoproterozoico a início do Paleozoico).

Sua estruturação é controlada por um sistema de cisalhamento transcorrente destral (Campanha, 1991, Campanha \& Sadowski, 1999, Campanha, 2002, Faleiros, 2008, Faleiros et al. 2010, 2011). 


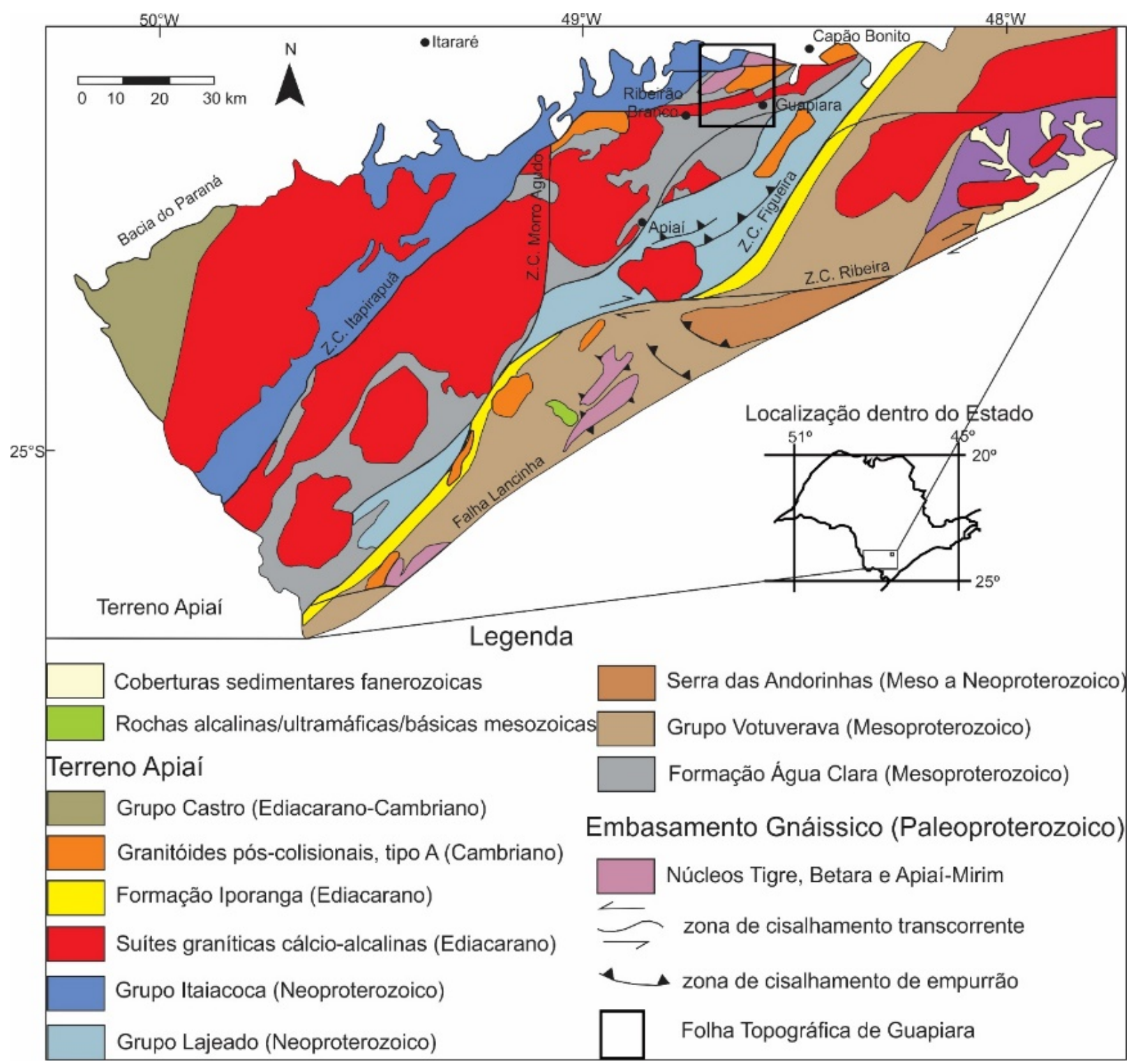

Figura 1. Mapa geológico regional com a localização da área da Folha Topográfica de Guapiara (Mod. de Faleiros, 2008).

O Cinturão Ribeira é dividido em sete terrenos: Varginha, Embu, Costeiro, São Roque, Apiaí, Curitiba, Paranaguá e Luiz Alves (Hasui, 2010, 2012). Como resultado, o cinturão é dominado por terrenos de origens distintas, separados por zonas de cisalhamento (Campanha, 2002, Heilbron et al., 2004, Faleiros, 2008, Faleiros et al., 2011, Santos et al., 2015).

De acordo com Campanha e Sadowski (1999), o Terreno Apiaí teve o começo de sua evolução no Paleo- e Mesoproterozoico, e consiste em sequências supracrustais de baixo a médio grau metamórfico, originalmente designadas como Grupo Açungui (Almeida, 1957, Petri \& Suguio, 1969), e posteriormente proposto como Supergrupo Açungui (Campanha, 1991, Campanha e Sadowski, 1999). Segundo Prazeres Filho et al. (2003) o terreno abrange uma faixa com aproximadamente $500 \mathrm{~km}$ por $100 \mathrm{~km}$, localizada na porção centro-sul do Cinturão Ribeira.

As rochas metassedimentares dominantes do Terreno Apiaí são constituídas pelo Supergrupo Açungui, assumidas de idade mesoproterozoica a ediacarana por Tassinari et al. (1990) e Fiori (1992, 1994) e teve a divisão estratigráfica na área em três unidades litotectônicas principais denominadas Formação Água Clara, Grupo Votuverava e Grupo Itaiacoca.

Datações minerais isotópicas U-Pb disponíveis (Hackspacher et al., 2000, Weber et al., 2004, Campanha et al., 2008, 2015, Siga Junior et al., 2009, 2011) indicam que o Terreno Apiaí foi formado pela amalgamação de unidades supracrustais cujas idades variam de Caliminiano (1500-1400 Ma: Formação Água Clara e Grupo 
Votuverava), a Toniano (1000-900 Ma: parte do Grupo Itaiacoca) e a Ediacarano (630-580 Ma: parte do Grupo Itaiacoca).

A Formação Água Clara, definida inicialmente por Marini et al. (1967), é subdividida em dois termos informais principais: (I) Unidade de Xistos dominada por litotipos silicáticos como micaxisto, quartzo micaxisto e xistos carbonáticos apontando para origem em ambiente marinho profundo e (II) Unidade Carbonática, composta por rochas calciossilicáticas e mármore calcítico puro a impuro, originada em domínio de plataforma continental rasa (Fiori, 1990, 1994; Kops, 1994). Destas reconheceu-se em campo um grande pacote de filitos sericíticos a quartzosos com intercalações de metacalcários variados (mármore, metacalcário e metacalciossilicatadas) e lentes de anfibolitos (Vieira, 2017).

Sequencialmente, ocorre o Grupo Votuverava, inicialmente definido por Bigarella \& Salamuni (1958), subdividido em cinco formações: Perau, Rubuquara, Nhunguara, Piririca e Ribeirão das Pedras, além de duas unidades informais: micaxisto e granada micaxisto, diferenciadas apenas por metamorfismo em níveis crustais distintos (Perrotta, 1996). É limitado, a sul, pela Zona de Cisalhamento Lancinha e, a norte, pelas zonas de cisalhamento Ribeira, Agudos Grandes e Figueira (Campanha, 1991). A unidade é composta por uma sequência metavulcanossedimentar, com magmatismo básico associado, na forma de lentes intercaladas de metabasitos (anfibólio xisto, fels, anfibolito) concordantes com as estruturas primárias (Petri \& Suguio, 1969, Campanha et al., 1987, Campanha \& Sadowski, 1999, Campanha et al., 2015). Na área predominam pacotes de quartzitos, xistos, além de lentes de actinolita xistos e anfibolitos (Vieira, 2017).

O Grupo Itaiacoca (Bistrichi et al., 1985) foi definido inicialmente como uma formação por Almeida (1956) e corresponde a duas sequências sedimentares, uma terrígena e outra química. Souza (1990) caracteriza a unidade terrígena pela ocorrência predominante de metassedimentos de natureza terrígena e, localmente, intercalações de rochas metavulcânicas e rochas com associações carbonáticas; e a unidade carbonática a uma sequência química, de metadolomitos e mármores intercalados a metamargas, estas últimas representadas por cálcio filitos e filitos carbonáticos.

Segundo Souza (1990), a sedimentação do Grupo Itaiacoca teria origem relacionada a um rifte continental, com evolução para margem continental passiva, comportando sedimentação de ambiente pouco profundo. Na região, é constituído por pacotes de quartzitos, metarritmitos, filitos, metarenitos e metarcóseos, metacalcários, além de lentes de actinolita xistos.

Mais a sul identifica-se o Grupo Lajeado que, segundo Campanha et al. (1987), corresponde a uma sequência progradacional regressiva de ambiente raso com influência de ondas (Pires, 1991), onde existe uma intercalação de rochas carbonática e siliciclásticas.

Em relação ao magmatismo neoproterozoico de caráter ácido, destaca-se o Complexo Granítico Três Córregos, dominado por biotitahornblenda monzogranito, biotita-hornblendaquartzo monzonito e granodiorito, com textura porfirítica e meacristais de feldspato potássico, deformados ou não (Fuck, 1967). São granitoides do Tipo I, com tendência cálcio-alcalina de alto $\mathrm{K}$ (Guimarães, 2000; Prazeres Filho et al., 2003). O corpo é representado por batólito de caráter tardia pós-tectônico, com alongamento na direção NESW, e composição litológica e textural relativamente homogêneas (Fuck, 1967).

O estudo dos granitoides pós-orogênicos a anorogênicos da Faixa de Dobramento Ribeira foi inicialmente proposto por Hasui et al. (1978), que individualizou os inúmeros corpos graníticos póstectônicos do estado de São Paulo. Segundo Prazeres Filho et al. (2003) e Bolonini \& Godoy (2013), o período pós-colisional anorogênico é marcado pela intrusão de plútons graníticos rasos, e inclui o corpo do Granito Capão Bonito.

Os processos sedimentares, tectônicos e metamórficos que configuram a evolução geológica da área mapeada mostram-se intimamente ligados aos eventos atuantes no Terreno Apiaí em contexto da fragmentação do Supercontinente Rodínia, da consequente instalação da Tafrogênese Toniana (Brito Neves, 1999, Fuck et al., 2008) e posterior formação do Gondwana, durante a Orogênese Brasiliana. Tal ciclo de ruptura registra diferentes etapas do Ciclo de Wilson, que Hasui $(2010,2012)$ apresenta como Ciclo dos Supercontinentes e que envolve fases de fragmentação, deriva de massas continentais e abertura oceânica. Segue-se então fases de convergência e aglutinação de tais massas, com fechamento dos oceanos e colisão de continentes. Por fim, tem-se o colapso do orógeno, com erosão e implementação de um 
regime distensivo.

A evolução do Terreno Apiaí remonta às sequências metassedimentares de idades meso- e neoproterozoica que foram acrescidas como um terreno durante o Neoproterozoico (Faleiros, 2008). Acredita-se que as sequências mesoproterozoicas desses terrenos registrem uma história metamórfica e de deformação anterior a instalação das bacias neoproterozoicas, apresentando em geral um metamorfismo na fácies xisto verde médio a anfibolito (Heilbron et al., 2004, Faleiros, 2008, Campanha et al., 2015).

O padrão deformacional dominante nas rochas supracrustais neoproterozoicas do Terreno Apiaí se deu inicialmente por etapa orogenética (Heilbron et al., 2004), com uma evolução marcada pela superposição de eventos.

$\mathrm{O}$ primeiro evento $D_{n}$ é relacionado a uma tectônica de cavalgamento, que gerou generalizada aloctónia dos tipos litológicos, acompanhado de estruturas geneticamente associadas, tais como falhas de cavalgamentos, dobras e a foliação $S_{n}$ (Fiori, 1993), enquanto a foliação $S_{n+1}$ seria gerada no evento $D_{n+1}$ também de cavalgamento, ambas progressivas. São identificadas dobras fechadas a isoclinais, centimétricas e de flanco rompido $S_{n+1}$, desenvolvidas sobre a foliação $S_{n}$ (Weber et al, 2004). Os dobramentos recumbentes mostram vergência para NW, constituindo o chamado Sistema de Cavalgamento Açungui (Fiori, 1993).

Superpondo-se a estas estruturas, ocorre um evento $D_{n+2}$, ligado à fase colisional final. É caracterizado por intenso escape lateral de direção NE-SW ligado a uma tectônica transcorrente/ transpressiva (Hackspacher et al., 2000).

Esse evento é responsável pelo dobramento das estruturas pré-formadas, como o acamamento reliquiar, o bandamento composicional e as foliações $S_{n}$ e $S_{n+1}$. As dobras são abertas a isoclinais, com plano axial NE-SW e inclinação superior a $60^{\circ}$, e pode ser verificado em diversas escalas, coincidentes com a foliação $\mathrm{S}_{\mathrm{n}+2}$ (Fiori, 1993). Esse evento foi denominado como Sistema de Dobramentos Apiaí (Fiori, 1993).

Nas proximidades das zonas de cisalhamento é observada a foliação $S_{n+2}$ paralela à foliação milonítica $\mathrm{S}_{\mathrm{m}}$, desenvolvida a partir de movimentações diferenciais dos blocos em condições de baixa temperatura (Campanha, 1991, 2002 e Faleiros, 2008). A essa tectônica se deve a presente configuração dos blocos e a colocação lado a lado de sequências com fácies metamórficas distintas (Hackspacher et al., 2000).

\section{QUADRO ESTRUTURAL}

A área apresenta grande complexidade tectônica, exibindo falhas de cavalgamento que separam domínios litoestratigráficos próprios e estas por sua vez estão cortadas por expressivas falhas transcorrentes destrais.

As estruturas principais denotam predominância de caráter dúctil para a deformação da área em estudo. O quadro estrutural da área baseia-se no mapeamento geológico da Folha Topográfica de Guapiara em 1:50.000 (Vieira, 2017) (Figura 2).

As rochas pré-cambrianas aflorantes estão estruturadas a partir de zonas de cavalgamento, cuja direção é aproximadamente NE, balizando grandes pacotes litológicos mais antigos (a SE) a cavalgar sequências cada vez mais jovens (a NW), em um complexo sistema de lascas tectônicas empurradas uma sobre as outras. Tais lascas possuem estratigrafia própria e podem ser constituídas por um ou mais tipos litológicos. Tal quadro é complicado por expressivo falhamento direcional, que justapõe três grandes domínios de idades distintas, denominados I, II e III (Figura 3).

O Domínio I é representado pelos metassedimentos da Formação Água Clara, o Domínio II é composto pelos metassedimentos do Grupo Votuverava e granitoides do Complexo Granítico Três Córregos e do Granito Capão Bonito e o Domínio III é constituído pelos metassedimentos do Grupo Itaiacoca.

Em geral, foram descritas $\mathrm{S}_{0}$ como as estruturas reliquiares e interpretadas quatro foliações principais, nomeadas como $S_{n}, S_{n+1}$, $\mathrm{S}_{\mathrm{n}+2}$ e $\mathrm{S}_{\mathrm{n}+3}$.

\section{Domínio I}

O domínio I é correspondente às rochas metassedimentares da Formação Água Clara, que afloram na parte sul da área mapeada da folha e da Zona de Cisalhamento Quarenta Oitava. Esta unidade é composta por metassedimentos, com predominância de filitos, e secundariamente por lentes de actinolita xistos, metacalcários e rochas calciossilicatadas. 


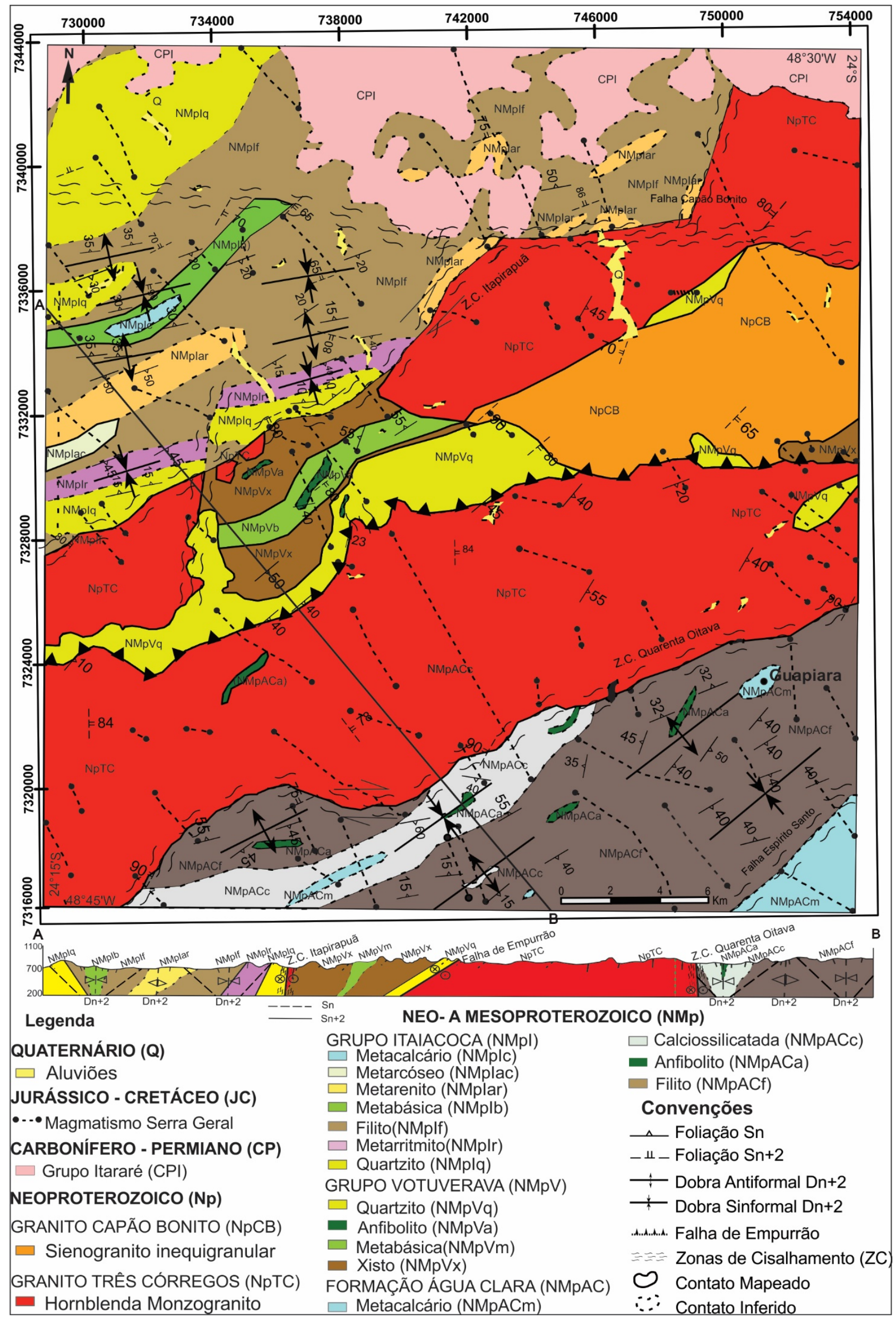

Figura 2 Mapa geológico da área da Folha Topográfica de Guapiara (Vieira, 2017). 


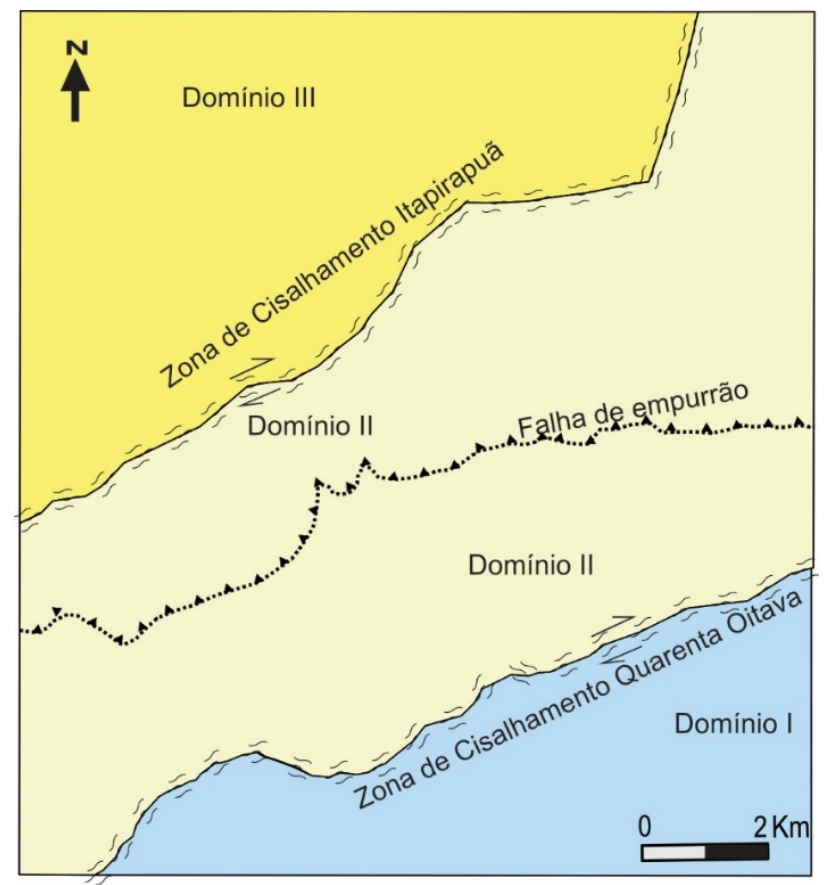

Figura 3 Divisão dos domínios estruturais da área da Folha Topográfica de Guapiara.

Nos metassedimentos da Formação Água Clara é possível reconhecer a foliação pelas intercalações entre lentes e camadas calcárias, sílticas e filíticas, que indicam sucessão de ambientes químicos e detríticos. No sericita filito, essa foliação é marcada por lâminas delgadas que apresentam quartzo e sericita em proporções variadas, originando porções às vezes rítmicas a depender da relação entre esses dois minerais.

Neste domínio, devido à intensa sobreposição de fases deformacionais aos litotipos mapeados, a ausência de estruturas primárias preservadas não permite caracterizar o bandamento composicional como $\mathrm{S}_{0}$, apesar da alternância dos litotipos sedimentares.

Os sericita-clorita filitos apresentam foliação bem marcada pelos cristais micáceos bem desenvolvidos. Esta feição evidencia a presença de um evento deformacional $D_{n}$, que orientou o crescimento dos cristais de micáceos, concentrando-os em finas lâminas paralelas ao bandamento composicional. A orientação preferencial é aproximadamente N18E, com mergulho de $27^{\circ}$ para NW (Figura 4A). É possível verificar um forte padrão de guirlanda, coerente com a interpretação de grandes estruturas sinclinais e anticlinais geradas durante o evento $D_{n+2}$.

A textura lepidoblástica destas rochas em lâmina delgada favorece a observação de planos de foliação transpostos por evento posterior à geração de $S_{n}$, e o mesmo encontra-se preservado dominantemente no micróliton (Figura 5A).

A foliação $S_{n+1}$ apresenta-se bem marcada por planos desenvolvidos de micas, discordante de Sn, correlacionada com um evento deformacional $\mathrm{D}_{\mathrm{n}+1}$, de natureza dúctil, responsável pela crenulação encontrada nos filitos quartzosos e sericíticos e pela formação de dobras isoclinais a recumbentes, com as foliações $S_{n}$ e $S_{n+1}$ paralelas nos flancos e oblíquas nas zonas de charneira. Nos metacalcários, é mascarada pela diferença de competência desta litologia em relação às demais. Predominantemente nos pacotes metassedimentares detríticos, nota-se a presença desta foliação $S_{n+1}$, com direção preferencial N70W/16SW dos planos de foliação e mergulhos de baixo ângulo tanto para NE, quanto para SW (Figura 4B).

O principal evento deformacional é $D_{n+2}$, de orientação preferencial NE/SW, com altos ângulos de mergulho e que tende a paralelizar a direção de $S_{n+2}$ às direções dos planos $S_{0}$ e $S_{n}$, obliterando as anteriores a partir de um bandamento tectônico. A orientação preferencial N82E/vertical, em concordância com o paralelismo do bandamento composicional (Figura 4C). Associada a foliação $\mathrm{S}_{\mathrm{n}+2}$ está um evento deformacional $\mathrm{D}_{\mathrm{n}+2}$, responsável pela formação de grandes dobras, com o plano $S_{n+2}$ correspondente ao plano axial das mesmas.

A última fase deformacional $D_{n+3}$ reconhecida na área foi responsável pelo dobramento da foliação $S_{n+2}$, e pela consequente geração localizada da foliação $S_{n+3}$. O evento $D_{n+3}$ gerou dobras centimétricas, abertas, assimétricas (Figura 5B). A foliação $\mathrm{S}_{\mathrm{n}+3}$ tem orientação preferencial de direção N80W/75SW, com mergulhos de alto ângulo, tanto para NE, quanto para SW (Figura 4D).

\section{Domínio II}

Este domínio, aflorante no centro da área de estudo, entre as zonas de cisalhamento Quarenta Oitava e Itapirapuã compreende as unidades metassedimentares do Grupo Votuverava e os granitoides do Complexo Granítico Três Córregos e o Granito Capão Bonito.

Litologicamente, predominam pacotes de quartzitos, biotita e muscovita xistos, além de lentes de actinolita xistos e anfibolitos, relativos ao Grupo Votuverava; hornblenda e biotita 
monzogranitos porfiríticos do Complexo Granítico Três Córregos; e sienogranitos porfiríticos do Maciço Granítico Capão Bonito. Assim como no Domínio I, devido à intensa sobreposição de fases deformacionais, e aos
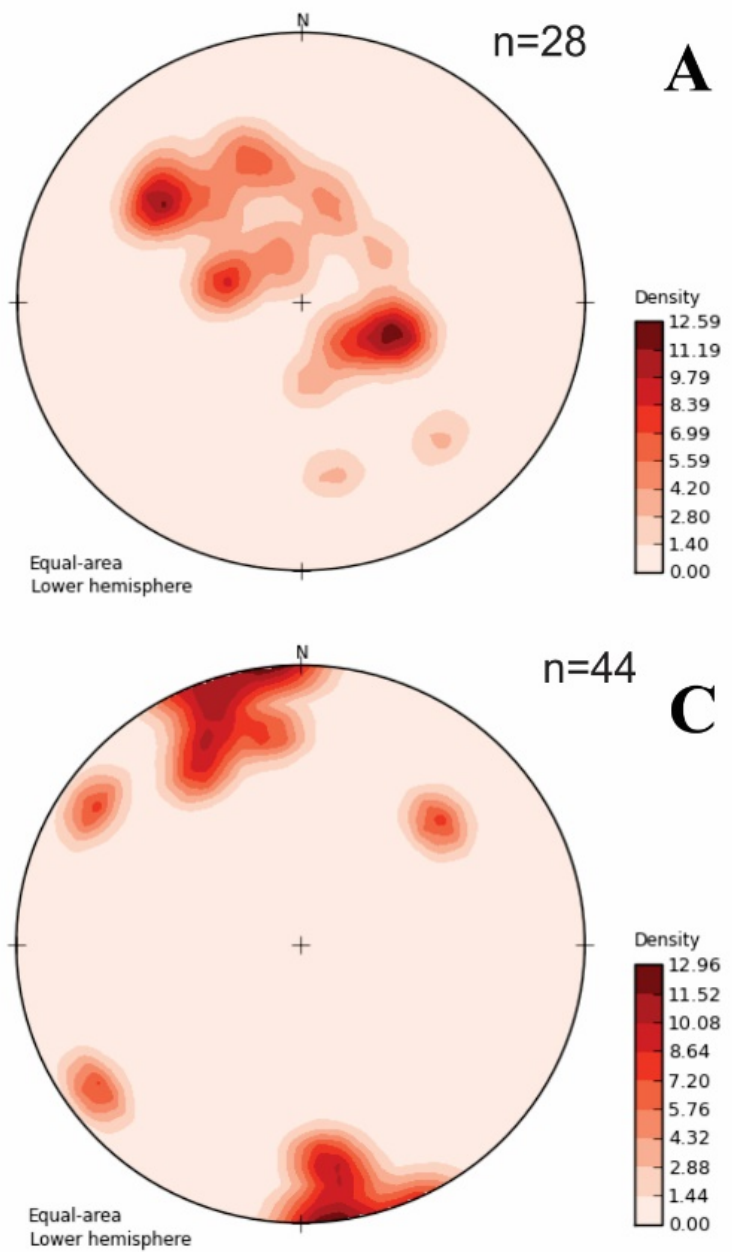

Figura 4 Estereogramas do Domínio I. A) $\mathrm{S}_{\mathrm{n}}$ (N18E/27SW), (N80W/75NE).

A principal foliação é $S_{n}$ nos metassedimentos e nos granitoides Três Córregos, com orientação preferencial NE/SW e baixos ângulos de mergulho, o que se deve à presença da falha de empurrão no centro do Domínio. O contato entre as unidades acima citadas é marcado fortemente por um trend NE/SW, reflexo da forte influência da foliação $S_{n+2}$. As estruturas geradas por $D_{n}$ reconhecidas foram foliações, dobras e zonas de empurrão de baixo ângulo. A foliação $S_{n}$ com atitude preferencial de N48E/38SE, constitui foliações com trend NE-SW de baixo ângulo, tanto nos granitoides quanto nos metassedimentos (Figura 6A), apresentando o mesmo padrão de guirlanda da foliação $\mathrm{S}_{\mathrm{n}}$ do Domínio I.

Já a foliação $S_{n+1}$ tem direção N30W/21SW (Figura 6B) e é marcada principalmente pelas litotipos encontrados os quais apresentam em sua maioria aspecto friável, não foram encontradas feições preservadas referentes ao bandamento composicional $\mathrm{S}_{0}$ das rochas metassedimentares
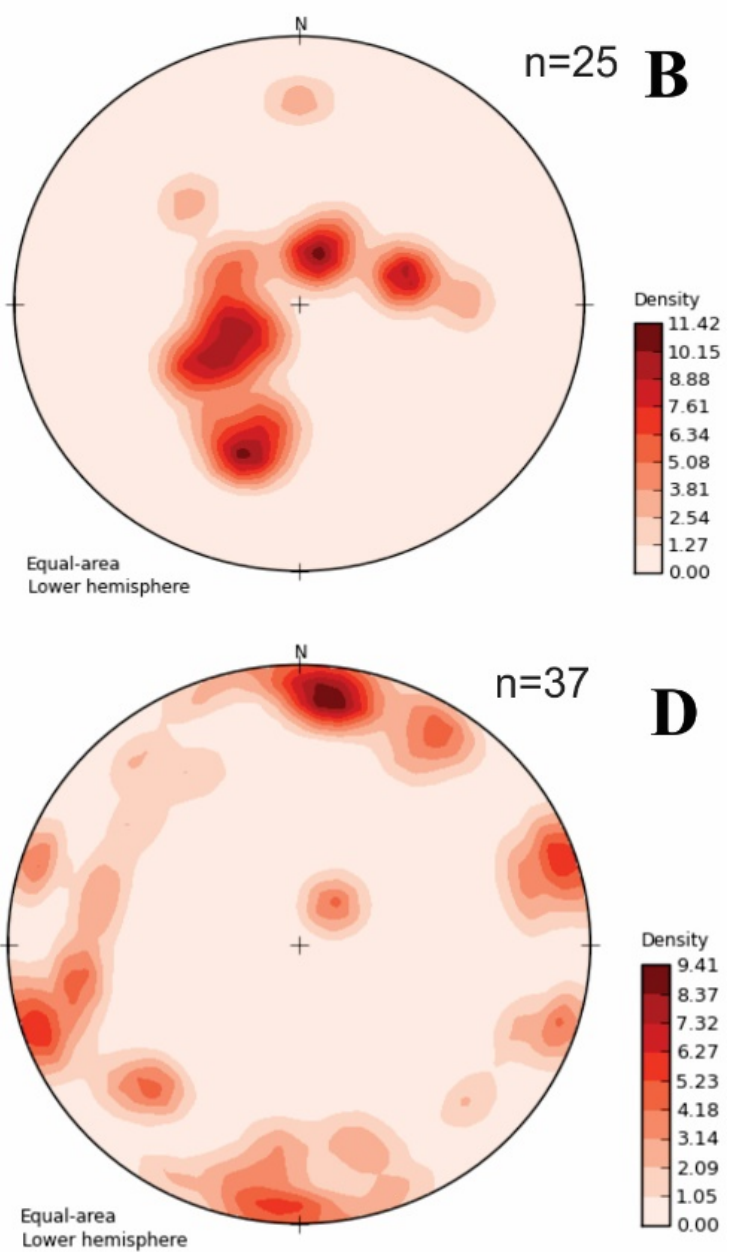

B) $S_{n+1}(N 70 W / 16 S W)$, C) $S_{n+2}(N 82 E / V e r t)$, D) $S_{n+3}$ crenulações de minerais micáceos ou de minerais prismáticos (actinolita-tremolita), ou mesmo em dobras de dimensões centimétricas e locais. Podem ser interpretadas como zonas de maior deformação, pela forte transposição relacionada a foliação $\mathrm{D}_{\mathrm{n}}$.

$O$ evento $D_{n+2}$ está associado com sistemas transcorrentes tardi-colisionais, e que geraram foliações de alto ângulo, orientadas segundo NE-SW, e dobramentos mais abertos, com eixos normalmente subhorizontais NE/SW e planos axiais subverticalizados. Este evento deformacional é marcante no domínio nos metassedimentos, e é o responsável pelas grandes feições morfológicas orientadas fortemente em um trend NE/SW e pela intrusão do corpo granítico pós-tectônico do Granito Capão Bonito. 

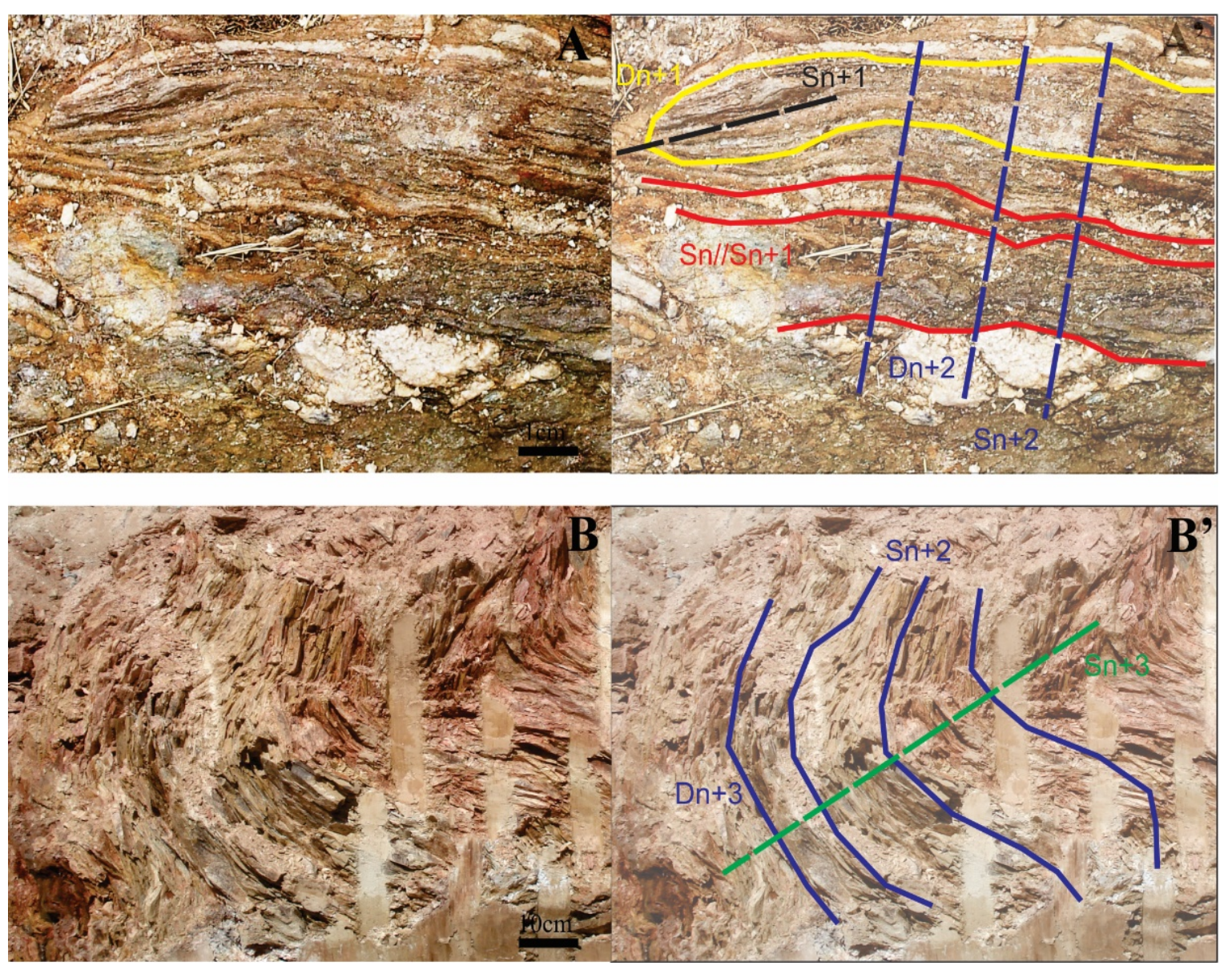

Figura 5 A) Superposição de deformação entre as foliações $S_{n}, S_{n+1}$ e $S_{n+2}$. A foliação $S_{n}$ apresenta-se dobrada pelo evento $D_{n+1}$ e, posteriormente, dobrada por $D_{n+2}$; B) Dobras relativas ao evento $D_{n+3}$, com plano axial $S_{n+3}$. A esquerda (A e B) foto do afloramento e a direita (A' e B') esquema enfatizando as estruturas observadas.

Os contatos entre as diferentes unidades do domínio II, orientados segundo este trend principal, são reflexos do evento $D_{n+2}$. A foliação $S_{n+2}$, possui atitude preferencial de N50E/83NW (Figura 6C) e quando presente normalmente oblitera as foliações pretéritas. É marcada por bandamento tectônico, com bandas mais ricas em micas nos quartzitos, e pela orientação preferencial de minerais micáceos ou prismáticos.

O evento $D_{n+3}$ está correlacionado com o evento $D_{n+2}$, ou seja, sistemas transcorrentes tardi-colisionais que geraram foliações de alto ângulo, com a diferença de estarem orientadas segundo NW/SE, e dobramentos abertos, com eixos normalmente subhorizontais NW/SE e planos axiais subverticalizados.

A deformação $D_{n+3}$, localmente, crenula as foliações pretéritas, o que gera dobras decimétricas a métricas (Figura 6B).

Em alguns pontos, é possível observar foliações de direção média N85W/69SW (Figura 6D), marcada pela orientação dos minerais micáceos presentes.

\section{Domínio III}

O domínio III é correspondente aos metassedimentos do Grupo Itaiacoca, que afloram a noroeste da área de estudo, acima na Zona de Cisalhamento Itapirapuã.

Diferente dos outros domínios, nestes metassedimentos estão preservam-se estruturas primárias que indicam que o bandamento composicional corresponde à estratificação reliquiar $\mathrm{S}_{0}$.

O acamamento reliquiar é definido pela alternância de porções mais micáceas e porções mais quartzosas (Figura 7A). São representadas na área por uma ritmicidade entre litotipos de quartzito e de quartzo xisto.

Os filitos sericíticos exibem uma laminação composicional marcada pela intercalação entre camadas submilimétricas a milimétricas de grãos de quartzo e outras com cristais de sericita. Os metarritmitos exibem esse bandamento da mesma forma que os filitos e também em maior escala pela intercalação de camadas até métricas mais ricas em quartzo com outras mais ricas em sericita e clorita. 

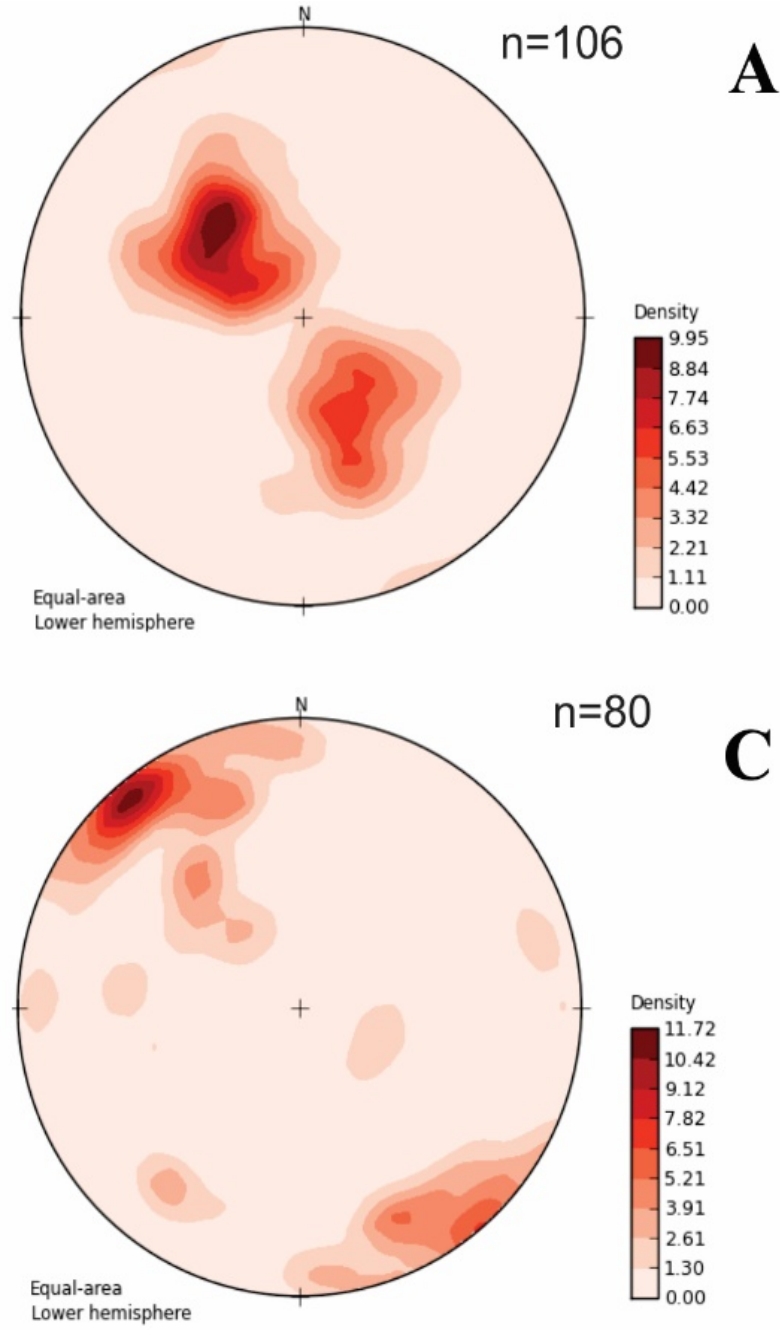
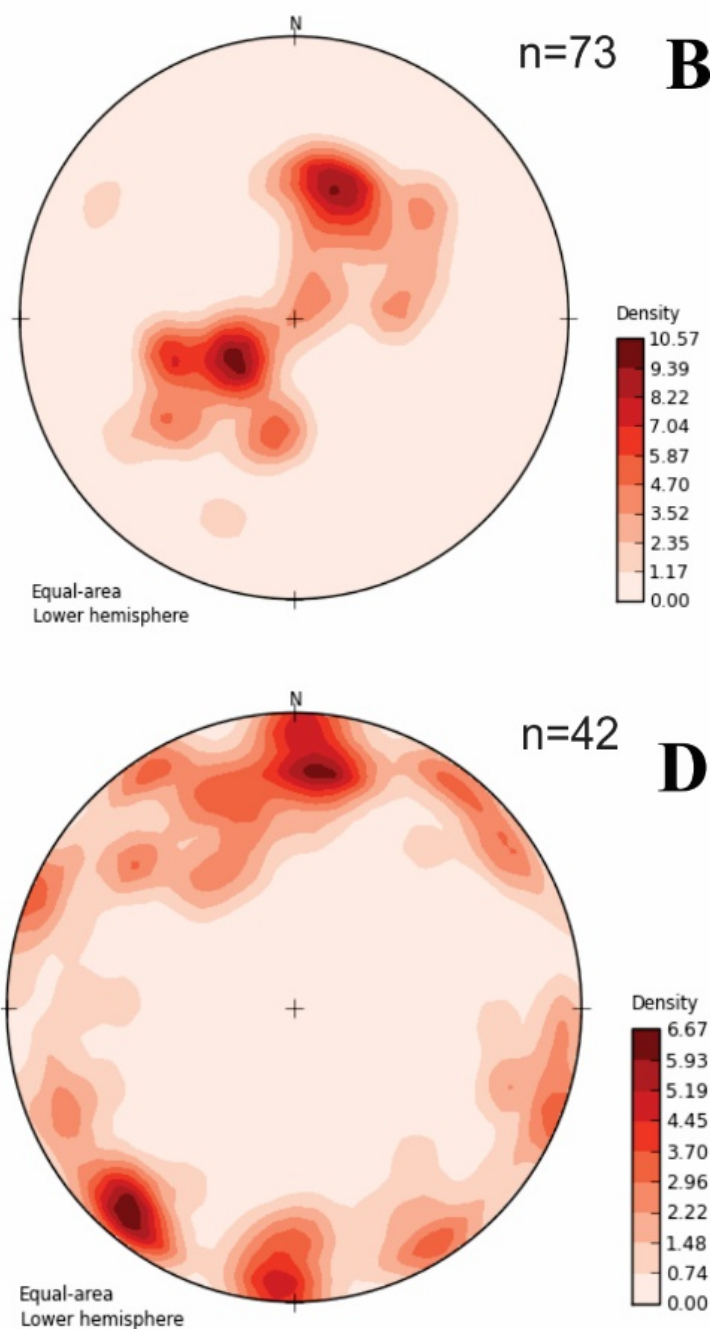

Figura 6 Estereogramas do Domínio II. A) $S_{n}$ (N48E/38SE), B) $S_{n+1}$ (N30W/21SW), C) $S_{n+2}(N 50 E / 83 N W)$, D) $S_{n+3}$ (N85W/69SW).

A foliação $S_{n}$ no geral ocorre paralelizada ao bandamento composicional. São bandas de diferentes granulometrias, com texturas distintas (porções granoblásticas e lépidoblásticas) e/ou bandas de diferentes colorações. Observam-se gradações de leitos mais micáceos e outros mais quartzosos, com a forte orientação de minerais micáceos de origem metamórfica, portanto, a foliação $S_{n}$.

A foliação $S_{n}$ possui dois máximos de concentração - N70E/33NW e N70E/33SE (Figura 8A)- e o estereograma apresenta padrão de guirlanda, com eixo na direção NE/SW.

A deformação $D_{n+1}$, de regime tectônico compressivo, gerou dobras apertadas a isoclinais (ângulo de $0^{\circ}$ a $30^{\circ}$ ), recumbentes e assimétricas (Figura 7B e C), com eixos e planos axiais predominantemente horizontais a sub-horizontais.

A clivagem ardosiana $S_{n+1}$ é penetrativa localmente, configurada por micas, agregados de quartzo levemente achatados e/ou cristais prismáticos de anfibólios (tremolita/actinolita/ hornblenda). Encontra-se paralelizada ao acamamento e ao bandamento composicional geralmente, sendo incomum e de natureza local quando diverge do mesmo (normalmente com ângulos e mergulhos variados).

Entende-se que a mesma ocorra em locais de maior deformação tectônica, obliterando evidências da foliação $S_{n}$ e do bandamento composicional nesses pontos, mas com os mesmos preservados em locais de menor deformação, com as estruturas sedimentares reliquiares com topo invertido, devido as dobras isoclinais.

A foliação $S_{n+1}$ possui como máximo de concentração a atitude N75W/27NE (Figura 8B).

A fase deformacional $D_{n+2}$ compreende um modelo de transpressão, de regimes dúcteis direcionais com movimentação destral.

$\mathrm{O}$ evento desenvolveu a foliação $S_{n+2}$, com alto ângulo de mergulho e direção preferencial 
N72E/83SE (Figura 8C), e gerou dobras com estilos abertos, cilíndricas, com os flancos mais inclinados e planos axiais verticalizados com direção NE (Figura 7D), e eixo NE/SW (com ângulo interflancos entre $50^{\circ}$ e $80^{\circ}$ ) de $\mathrm{S}_{\mathrm{n}+1} / / \mathrm{S}_{\mathrm{n}} / / \mathrm{S}_{0}$.

A foliação $S_{n+2}$ é uma xistosidade contínua ou espaçada marcada pelo rearranjo de prismas de anfibólios ou rotação de filossilicatos. É penetrativa em todo o conjunto litológico, embora em certos locais com dobras $D_{n+2}$ só seja possível observar a foliação $S_{n+1} / / S_{n}$ dobrada, sem uma aparente formação de um plano axial $S_{n+2}$. A lineação possui caráter penetrativo nas litologias deformadas, do tipo mineral (definida pela orientação de grãos de quartzo e/ou de placas micáceas) ou de estiramento, marcada por agregados de quartzo fortemente estirados.

A quarta fase deformacional $\mathrm{D}_{\mathrm{n}+3}$ é representada por uma ondulação e/ou crenulação da foliação $S_{n+2}$. Gerou, portanto, pequenas dobras (crenulações) abertas com plano-axial vertical com direção NE e uma foliação de orientação preferencial N60E/83NW (Figura 8D).

Os eixos destas dobras possuem mergulhos de alto ângulo (até $90^{\circ}$ ) para NE. Tais elementos lineares não se mostram deformados, o que sugere ser a fase $D_{n+3}$ o último evento tectônico da área.

De maneira geral, é possível integrar as fases estruturais $S_{0}, S_{n}$ e $S_{n+1}$ e $S_{n+2}$ descritas nos três domínios acima em um único quadro evolutivo para a região, como proposto na figura 9. Tratase, portanto, da verticalização das foliações $S_{n}$ e $\mathrm{S}_{\mathrm{n}+1}$, que se tornam paralelas devido a deformação, embora em alguns pontos seja possível vislumbrar o resquício de dobras fechadas com plano axial relativo a $S_{n+1}$.

\section{Juntas}

No diagrama das juntas (Figura 10A) nota-se a formação de ao menos dois máximos de concentração para os planos destas descontinuidades. O máximo de maior concentração corresponde ao plano N50W/80SW e o segundo máximo em concentração corresponde ao plano N55W/80NE (Figura 10B).
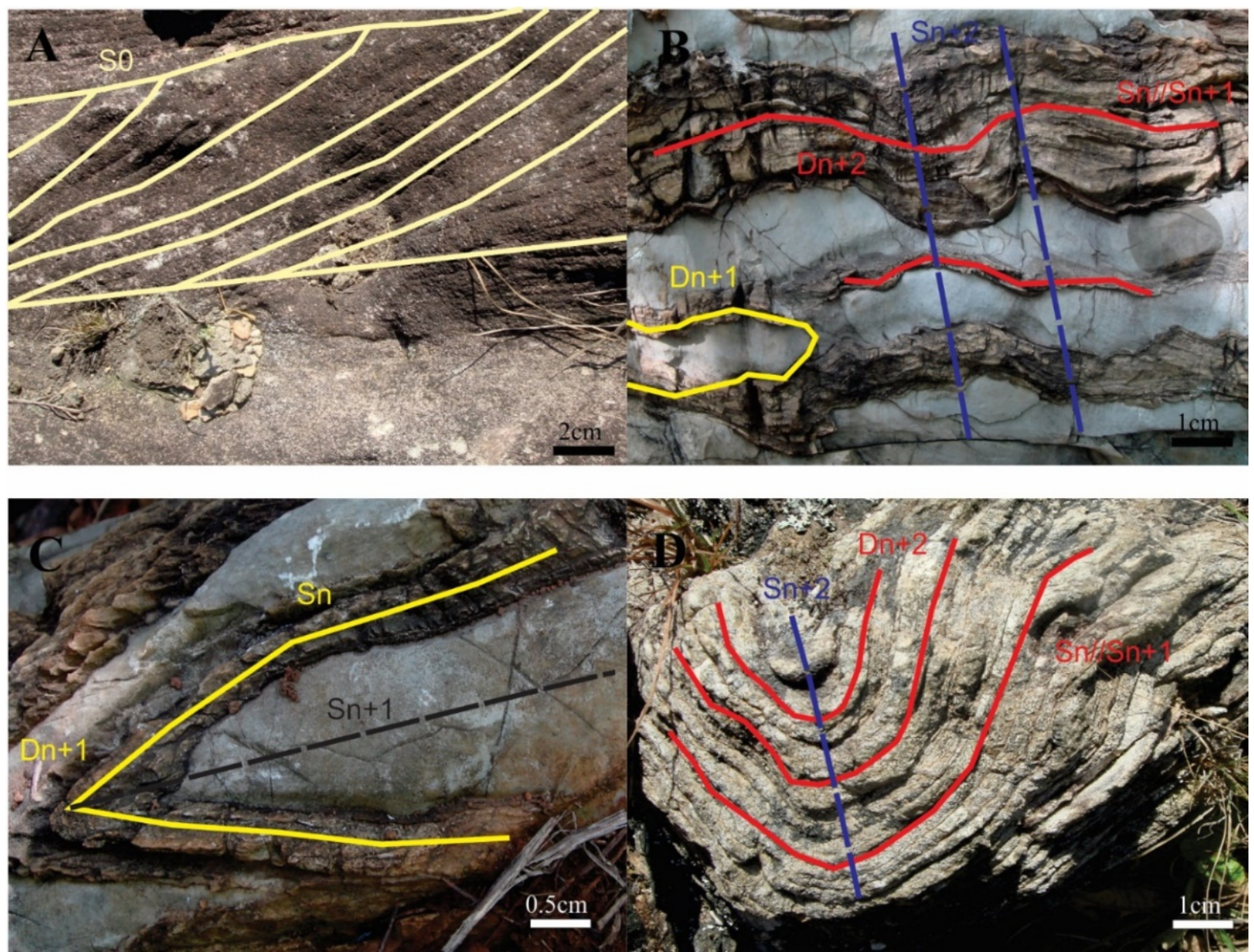

Figura 7 A) Estratificação cruzada tangencial na base em metarenitos, indicando o $\mathrm{S}_{0}$ preservado, B) Superposição de deformação dos eventos $D_{n}, D_{n+1}$ e $D_{n+2}$, C) Padrão de dobra fechada relativa ao evento $D_{n+1}$, D) Padrão de dobra aberta relativa ao evento $D_{n+2}$. 

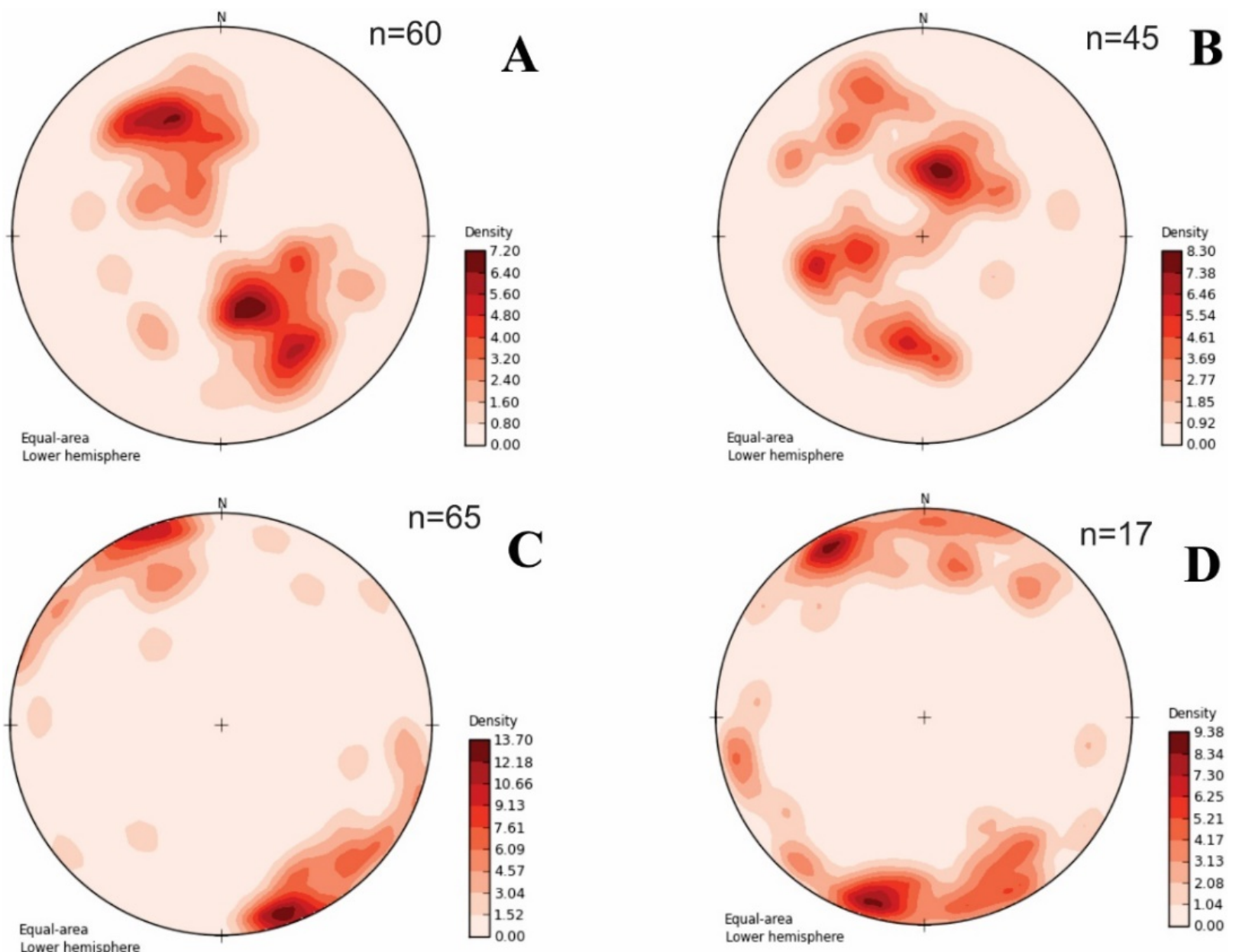

Figura 8 Estereogramas do Domínio III. A) $S_{n}$ (N70E/33NW), B) $S_{n+1}$ (N75W/27NE), C) $S_{n+2}$ (N72E/83SE), D) $S_{n+3}$ (N60E/83NW).

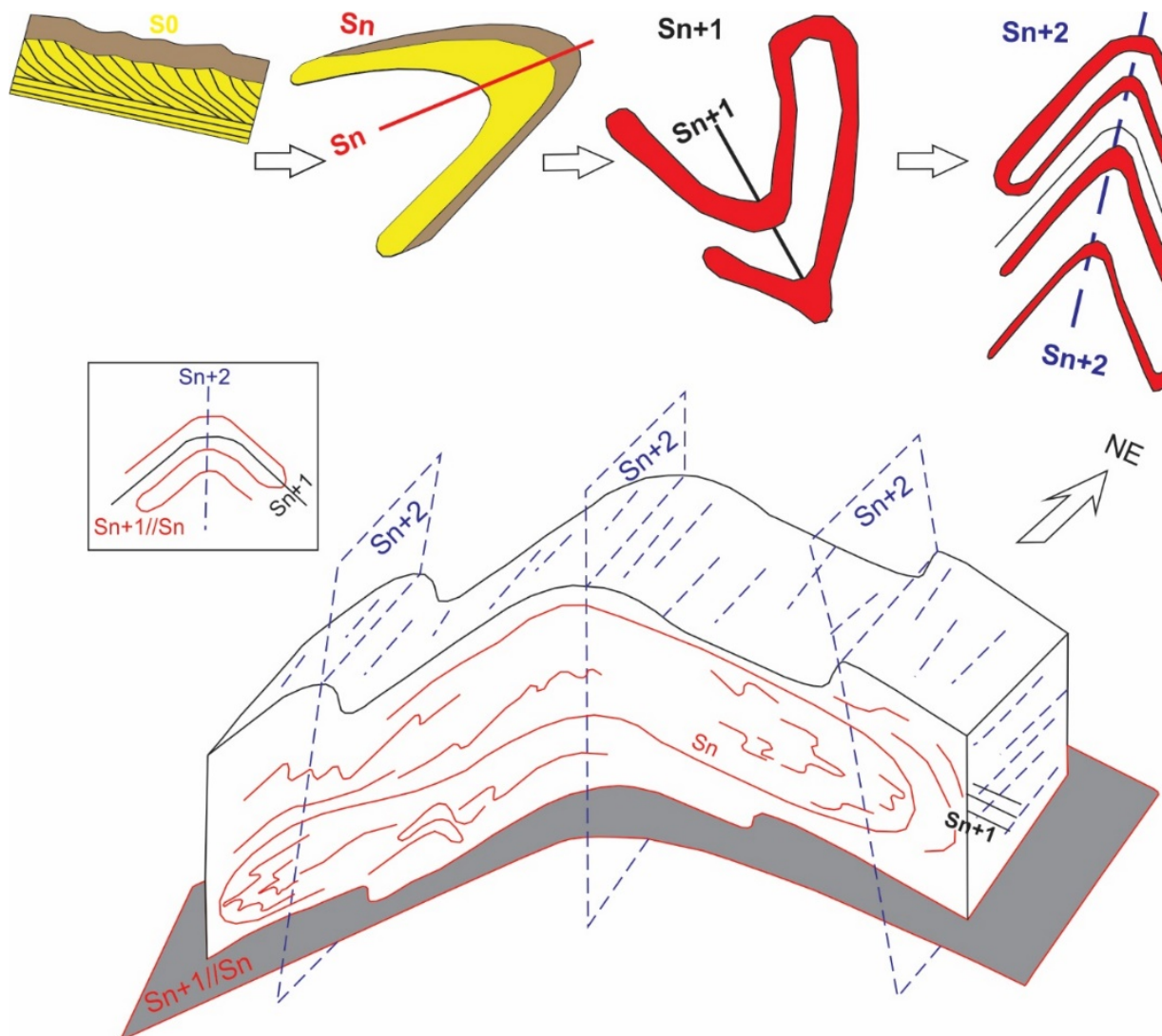

Figura 9 - Quadro estrutural regional para a área da Folha Topográfica de Guapiara. 

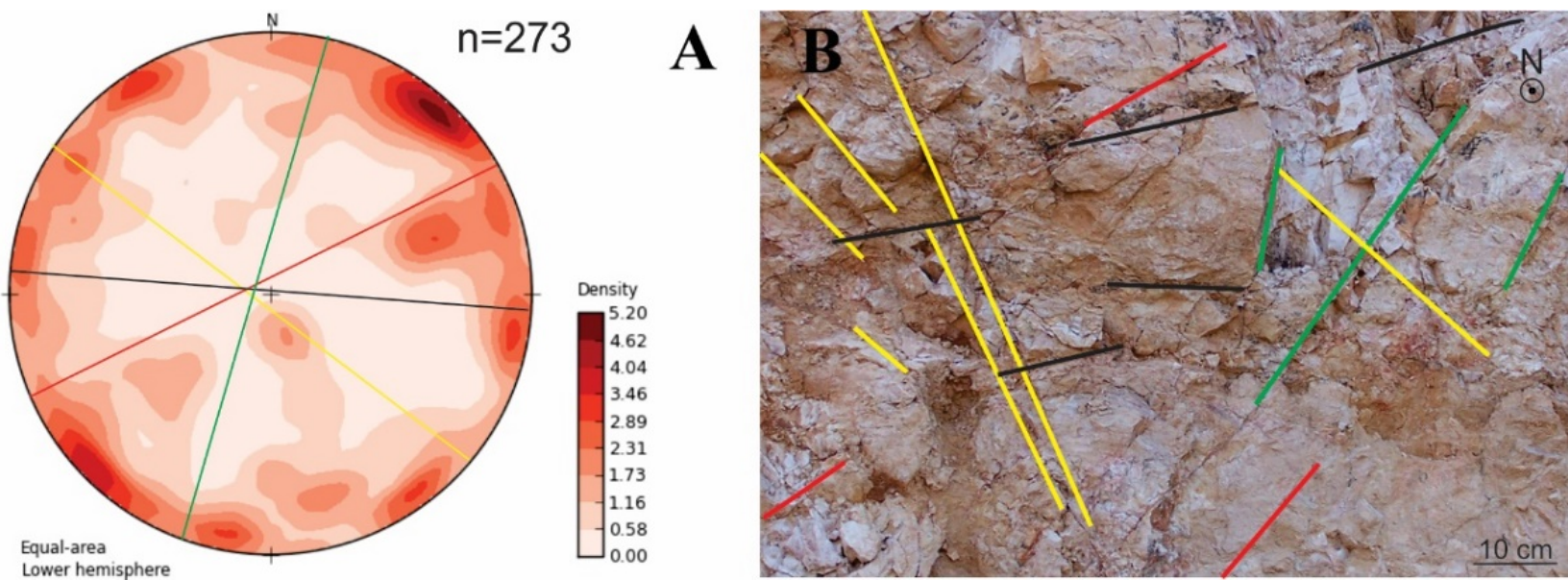

Figura 10 A) Estereograma das juntas na área. Os traços amarelo, vermelho, verde e preto representam os planos de máximo de concentração e estão representados na figura ao lado de maneira análoga, B) Padrão de fraturamento observado em campo.

Um terceiro máximo de concentração, em menor escala, corresponde ao plano EW/ subvertical e um quarto máximo de direção N20E/subvertical. Para estas diaclases são considerados todos os litotipos.

Tais diaclases foram classificadas quanto à superfície da descontinuidade, na maioria dos casos lisa e poucas vezes áspera, a geometria das superfícies é plana, o espaçamento da família principal, bem como das demais famílias, possui uma distância média de 0,1 a $1,5 \mathrm{~m}$ e a abertura das juntas é mili- a centimétrica.

\section{Falha de Empurrão}

A falha de empurrão é a principal característica distintiva do Domínio II, mapeada e delimitada no centro do mesmo, como o contato entre as rochas granitoides do Complexo Granítico Três Córregos e os metassedimentos do Grupo Votuverava.

A falha é marcada por foliações de baixo ângulo, relacionadas aos eventos $D_{n}$ e $D_{n+1}$, com direções preferencias NE/SW com mergulhos de até $30^{\circ}$ para NW. A direção do empurrão é NW, o que corrobora as idades atribuídas aos metassedimentos da Formação Água Clara, Grupo Votuverava e Grupo Itaiacoca, que são empurrados pelas rochas granitoides.

A falha gerou, assim como possibilitou a intrusão dos granitoides sin-colisionais, dobras apertadas a isoclinais, recumbentes com planos axiais e linhas de charneiras subhorizontais, "desenhadas" pelo acamamento $\mathrm{S}_{0}$ e/ou bandamento composicional $\mathrm{S}_{\mathrm{n}}$.

\section{Zonas de Cisalhamento Transcorrente}

As zonas de cisalhamento transcorrentes (rejeito direcional) aparecem como a seccionar os domínios. Estes falhamentos direcionais podem ser correlacionáveis as Zona de Cisalhamento Quarenta Oitava, a sul do mapa, e Zona de Cisalhamento Itapirapuã, a norte do mapa. São de natureza dúctil a dúctil-rúptil, com predominância do primeiro, e justapõe três pacotes tectono-estratigráficos de idades distintas. As rochas por elas afetadas apresentam feições miloníticas a cataclasíticas (Figura 11A, B). A lineação apresenta-se sub-horizontal, marcada pelo estiramento de quartzo, feldspato, biotita e anfibólio ou pela orientação de clastos/ porfiroclastos de feldspato potássico.

A foliação milonítica é marcada por lâminas descontínuas de minerais máficos fragmentados e finamente recristalizados intercalados com lâminas e lentes de quartzo e feldspatos. Também são visíveis indicadores de sentido de cisalhamento destral, relacionados com a Zona de Cisalhamento Itapirapuã (Figura 11C e D).

Estas duas zonas transcorrentes destrais foram geradas durante os eventos deformacionais da fase $\mathrm{D}_{\mathrm{n}+2}$, e são responsáveis, pela geração da foliação milonítica $\mathrm{S}_{\mathrm{n}+2}$ e da foliação $\mathrm{NE}$ subvertical $\mathrm{S}_{\mathrm{n}+2}$.

As dobras são sin-transcorrentes, abertas a suaves, com a linha de charneira com caimentos suaves para NE (paralelo a lineação mineral/ estiramento) e ao plano-axial vertical desta fase. 


\section{DISCUSSÕES E CONCLUSÕES}

O arcabouço geológico da região de Guapiara envolve rochas da sequência metavulcanossedimentar do Supergrupo Açungui, de idade mesoproterozoica, metamorfizadas e deformadas no Neoproterozoico, associadas a um conjunto de rochas granitoides gerados durante os episódios colisionais ligados à formação do Supercontinente Gondwana.

O quadro estrutural é determinado dominantemente pelo arranjo tectônico neoproterozoico, identificado nas rochas epimetamórficas do Supergrupo Açungui. As rochas apresentam uma evolução estrutural do tipo polifásica, evidenciada pelo registro principalmente de quatro fases deformacionais $D_{n}, D_{n+1}, D_{n+2}$ e $D_{n+3}$.

As estruturas primárias, devido aos intensos processos de transposição das foliações $S_{n}$ e $\mathrm{S}_{\mathrm{n}+1}$ e deformação milonítica, associadas à deformação de alto ângulo $S_{n+2}$, ocorrem de forma escassa, com predominância somente do acamamento gradacional reliquiar $\mathrm{S}_{0}$, nas áreas menos deformadas (Domínio III). Nas zonas que ocorrem a deformação de alto ângulo, nas regiões de zona de cisalhamento, superpõem-se as demais estruturas planares, um bandamento tectônico.
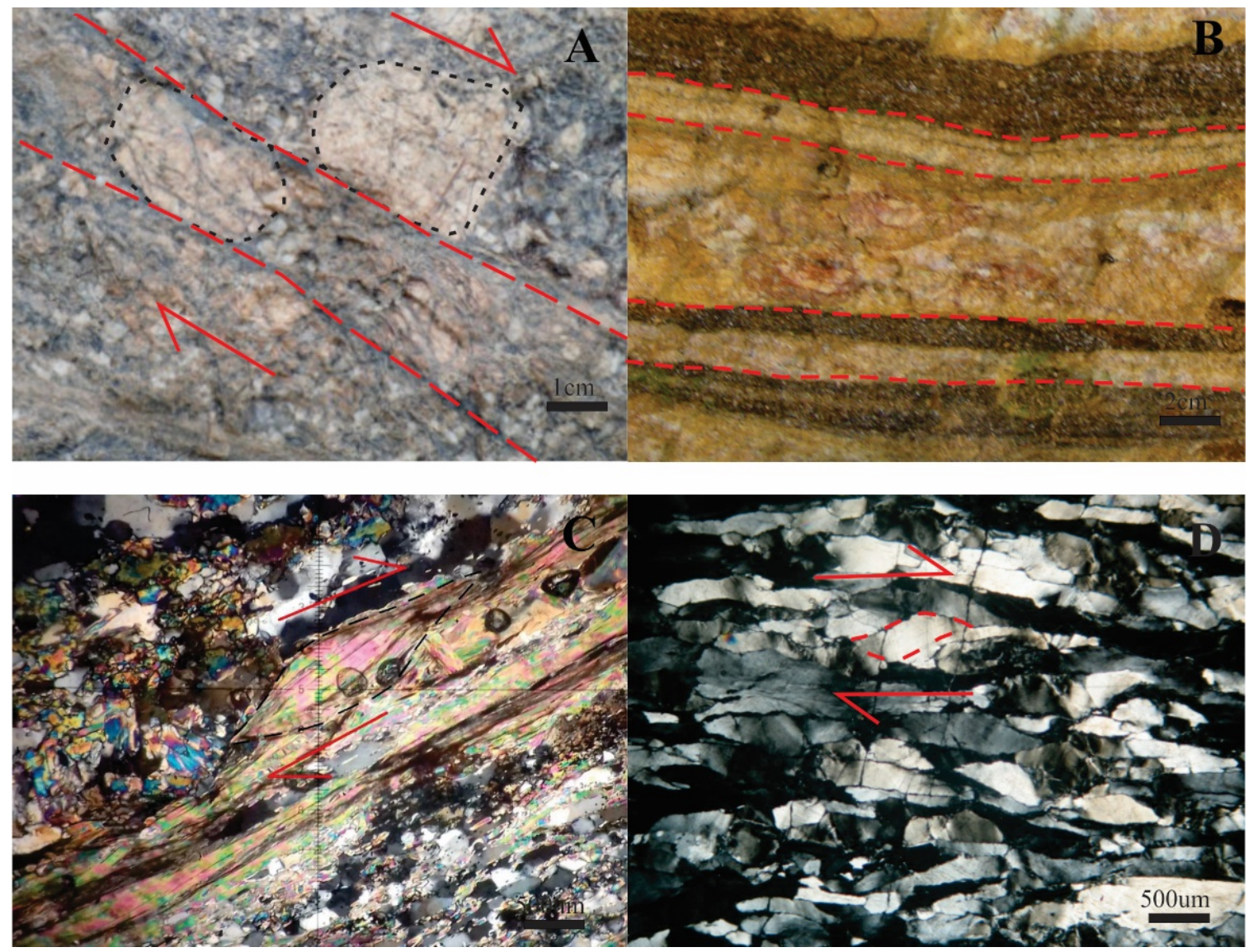

Figura 11 A e B) evidências de cataclasamento e milonitização dos granitoides e metassedimentos, C e D) indicadores cinemáticos destrais

As deformações progressivas tangenciais $D_{n}$ e $D_{n+1}$ encontram-se associadas ao início do processo colisional, associadas às zonas de cavalgamento e relacionadas às fases iniciais da orogênese.

O primeiro evento deformacional $D_{n}$ é responsável por dobramentos isoclinais a recumbentes, fechados, decimétricas a métricas, com foliação plano-axial $S_{n}$ de baixo a médio ângulo e direção preferencial N30E/30NW, subparalela ao bandamento composicional.

$\mathrm{O}$ segundo evento deformacional $\mathrm{D}_{\mathrm{n}+1}$ constitui uma foliação plano-axial identificada por uma clivagem ardosiana penetrativa ou uma de clivagem de crenulação $S_{n+1}$ não penetrativa e espaçada milimétrica a centimetricamente entre porções da rocha. Apresentam atitude N40W/30SW, com mergulhos com variações de baixo a médio.

A granitogênese sin- colisional associa-se a 
uma tectônica dúctil $\mathrm{D}_{\mathrm{n}+1}$ com emplacement das rochas do Complexo Granítico Três Córregos, vista principalmente na reorientação dos minerais máficos (biotita e hornblenda) e a geração de porfiroblastos nas auréolas de metamorfismo de contato desenvolvidas lateralmente aos corpos ígneos. Esta relação estrutural, com corpos graníticos que apresentam foliação de baixo ângulo, ressalta o caráter sin- cinemático do emplacement magmático ao evento tectônico $D_{n+1}$ do Supergrupo Açungui.

$O$ terceiro evento deformacional $D_{n+2}$ envolve esforços transpressivos em caráter dúctil-rúptil e retrometamórfico e é definida pela formação de amplas dobras normais, suaves a abertas (sinformais e antiformais) e sanfonadas de eixo sub-horizontal, com uma tênue clivagem subvertical, com plano axial de atitude N60E/75SE.

A foliação $S_{n+2}$ é penetrativa nas zonas de cisalhamento, e apresenta indicativos de movimentos basicamente de caráter destral, o que caracteriza uma foliação milonítica, com a geração de filonitos com bandamento tectônico que oblitera estruturas reliquiares sedimentares e regionalmente as paragêneses de metamorfismo de contato.

A deformação $D_{n+2}$ ocorre associada à ascensão magmática tardia das rochas póscolisionais do Granito Capão Bonito, associadas a zonas de cisalhamento e a atual estruturação alongada do maciço encontra-se correlacionada a esta deformação. As rochas granitoides evidenciam um caráter fracamente milonítico e/ou cataclástico nas suas bordas, quando expostos os seus contatos com as rochas encaixantes, com o contato norte a partir da Zona de Cisalhamento Itapirapuã e o contato sul através da Zona de Cisalhamento Quarenta Oitava. A fase deformacional $\mathrm{D}_{\mathrm{n}+3}$ apresenta dobras similares ao evento anterior, mas com plano axial com direção NW/SE e é identificada por uma tênue foliação ou clivagem de fratura de direção N45W/80SW.

Tardiamente observam-se diques básicos intrusivos controlados por um trend de direção principal NW-SE, que são correlatos aos diques que se encaixam na direção das juntas e enxames de diques associados ao Lineamento Guapiara (NW-SE), associadas ao magmatismo mesozoico da Formação Serra Geral.

\title{
AGRADECIMENTOS
}

\author{
Os autores externam os agradecimentos ao apoio do CNPq proc. nº: 304614/2017-3.
}

\section{REFERÊNCIAS}

ALMEIDA, F.F.M. Novas ocorrências de fósseis no PréCambriano brasileiro. Anais da Academia Brasileira de Ciências, v. 29, n. 1, p. 63-72, 1957.

ALMEIDA, F.F.M. Origem e evolução da Plataforma Brasileira. Rio de Janeiro. Boletim DNPM/DGM, v. 241, 38 p., 1967.

ALMEIDA, F.F.M.; HASUI, Y., BRITO-NEVES, B.B.; FUCK, R.A. Províncias estruturais brasileiras. SIMPÓSIO GEOLOGIA NORDESTE, 8, 1977. Campina Grande. Anais... Recife: SBG, p. 363-391, 1977.

ALMEIDA, F.F.M.; HASUI, Y.; PONÇANO, W.L.; DANTAS, A.S.L.; CARNEIRO, C.D.R.; MELO, M.S.; BISTRICH, C.A. Mapa Geológico do estado de São Paulo em escala 1: $\mathbf{5 0 0 . 0 0 0 .}$ Nota explicativa. São Paulo, IPT, Monografias 6, v. 1, 126 p., 1981.

BASEI, M.A.S.; SIGA JUNIOR, O.; MACHIAVELLI, A.; MANCINI, F. Evolução tectônica dos terrenos entre os cinturões Ribeira e Dom Feliciano (PR-SC). Revista Brasileira de Geociências, Curitiba, v. 22, p. 216-221, 1992.

BASEI, M.A.S.; SIGA JUNIOR, O.; KAULFUSS, G.A.; CORDEIRO, H.; NUTMAN, A.; SATO, K.; CURY, L.F.; PRAZERES FILHO, H.J.; PASSARELLI, C.R.; HARARA, O.M.; REIS NETO, J.M.; WEBER; W. Geochronology and isotope geochemistry of Votuverava and Perau Mesoproterozoic Basins, Southern Ribeira Belt, Brazil. In: SOUTH AMERICAN SYMPOSIUM ON ISOTOPE GEOLOGY (SHORT PAPERS), IV, 2003. Anais...São Paulo.

BIGARELLA, J.J. \& SALAMUNI, R. Estudos preliminares na Série Açungui: VII - A Formação Votuverava. Curitiba, Instituto de História Natural, Geologia, Boletim 2, 60p., 1958.

BISTRICHI, C.A.; CARNEIRO, C.D.R.; DANTAS, A.S.L.; PONÇANO, W.L.; CAMPANHA, G.A.C.; NAGATA, N.; ALMEIDA, M.A.; STEIN, D.P.; MELO, M.S.; CREMINI, O.A. Mapa geológico do Estado de São Paulo em 1: 500.000. IPT/Pró-Minério, São Paulo, v. 2, 1981.

BISTRICHI, C.A.; ALMEIDA, M.A.; STEIN, D.P. Geologia das folhas Barra do Chapéu (SG.22-X-B-I-4) e Araçaíba (SG.22-XF-II-3), estados de São Paulo e Paraná. São Paulo, Contrato IPT/ Pró-Minério, vol. 1, 104 p. (IPT. Relatório 22.150), 1985.

BOLONINI, T.M. \& GODOY, A.M. Geologia e Geoquímica das rochas graníticas do Maciço Capão Bonito, SP. São Paulo, UNESP, Geociências, v. 32, n. 3, p. 452-470, 2013.

BRITO NEVES, B.B.B. América do Sul: quatro fusões, quatro fissões e o processo acrescionário andino. Revista Brasileira de Geociências, v. 29, n. 3, p. 379-392, 1999.

CAMPANHA, G.A.C. Tectônica Proterozoica no Alto e Médio Vale do Ribeira, Estados de São Paulo e Paraná. 1991, 296 p. Tese (Doutorado). Instituto de Geociências, Universidade de São Paulo, São Paulo, 1991.

CAMPANHA, G.A.C. O papel do sistema de zonas de cisalhamento transcorrentes na configuração da porção meridional da Faixa Ribeira, 2002. 105 p. Tese (LivreDocência), Instituto de Geociências, Universidade de São Paulo, São Paulo, 2002.

CAMPANHA, G.A.C. \& SADOWSKI, G.R. Tectonics of the southern portion of the Ribeira Belt (Apiaí Domain). 
Precambrian Research, v. 98, p. 31-51, 1999.

CAMPANHA, G.A.C.; BISTRICHI, C.A.; ALMEIDA, M.A. Considerações sobre a organização litoestratigráfica e evolução tectônica da faixa de dobramentos Apiaí. In: SIMPÓSIO SUL-BRASILEIRO DE GEOLOGIA, 3. Curitiba, 1987. Atas...Curitiba: SBG, v. 2, p. 725-742, 1987.

CAMPANHA, G.A.C.; BASEI, M.A.S; TASSINARI, C.C.G.; NUTMAN, A.P.; FALEIROS, F.M. Constraining the age of the Iporanga Formation with shrimp U-Pb zircon: implications for possible ediacaran glaciation in the Ribeira belt, SE Brazil. Gondwana Research, v. 13, p. 117-125, 2008.

CAMPANHA, G.A.C.; FALEIROS, F.M.; BASEI, M.A.S.; TASSINARI, C.C.G.; NUTMAN, A.P.; VASCONCELOS, P.M. Geochemistry and age of mafic rocks from the Votuverava Group, southern Ribeira Belt, Brazil: Evidence for 1490Ma oceanic back-arc magmatism. Precambrian Research, v. 266, p. 530-550, 2015.

CHIODI FILHO, C.; TAKAHASHI, A.T.; SILVA, C.R.; FERREIRA, J.C.G. Projeto Capão Bonito. Relatório Final CPRM, v. I, Rio de Janeiro, 121 p., 1983.

COMPANHIA DE PESQUISA DE RECURSOS MINERAIS. Geologia e Recursos Minerais do Estado de São Paulo: Sistemas de Informações Geográficas (SIG). Brasília: MME, Programa Geologia do Brasil: Integração, Atualização e Difusão de Dados da Geologia do Brasil, Mapas Geológicos Estaduais. Escala 1:750000, CD-ROM, 2006.

FALEIROS, F.M. Evolução De Terrenos TectonoMetamórficos Da Serrania Do Ribeira E Planalto Do Alto Turvo (SP, PR), 2008. 306p. Tese (Doutorado). Instituto de Geociências da Universidade de São Paulo, São Paulo, 2008.

FALEIROS, F.M.; CAMPANHA, G.A.C.; BELLO, R.M.S.; FUZIKAWA, K. Quartz recrystallization regimes, c-axis texture transitions and fluid inclusion re-equilibration in a prograde greenschist to amphibolite facies mylonite zone (Ribeira Shear Zone, SE Brazil). Tectonophysics, v. 485, p. 193-214, 2010.

FALEIROS, F.M.; FERRARI, V.C.; COSTA, V.S.; CAMPANHA, G.A.C. Geoquímica e petrogênese de metabasítos do grupo Votuverava (Terreno Apiaí, Cinturão Ribeira Meridional): evidências de uma bacia retro arco caliminiana. Geologia USP, Série Científica, v. 11, n. 2, p. 135-155, 2011.

FASSBINDER, E. A unidade Água Clara no contexto do Grupo Açungui: um modelo transpressivo de colisão oblíqua no Neoproterozoico paranaense, 1996. 207p. Tese (Doutorado). Instituto de Geociências, Universidade de São Paulo, São Paulo, 1996.

FIORI, A.P. Tectônica e estratigrafia do Grupo Açungui a norte de Curitiba, 1990. 261p. Tese (Livre Docência). Instituto de Geociências, Universidade de São Paulo, 1990.

FIORI, A.P. Tectônica e estratigrafia do Grupo Açungui, PR. Boletim IG-USP. Série Científica, v. 23, p. 55-74, 1992.

FIORI, A.P. Evolução geológica da bacia Açungui. Boletim Paranaense de Geociências, v. 42, p. 7-27, 1994.

FUCK, R.A. Contribuição ao estudo das rochas graníticas do Estado do Paraná. Boletim Paranaense Geociências. v. 23/25, p. 183-221, 1967

FUCK, R.A.; BRITO NEVES, B.B.B.; SCHOBBENHAUS, C. Rodínia descendants in South America. Precambrian Research, v. 160, n. 1-2, p 108-126, 2008.

HACKSPACHER, P.C. \& GODOY, A.M. Vertical Displacement During Post-Colisional Escape Tectonic (Brasiliano Orogeny) of The Ribeira Belt, São Paulo, Brazil. Journal of African Earth Sciences. Elsevier Science Ltd., Africa do Sul, v. 29, n. 1, p. 25-32, 1999.

HACKSPACHER, P.C.; DANTAS, E.L.; SPOLADORE, A.; FETTER, A.H., OLIVEIRA, M.A.F. Evidence of Neoproterozoic back arc basin development in the Central Ribeira Belt, Southeastern Brazil new geochronological and geochemical constraints from São Roque Açungui groups. Revista Brasileira de Geociências, v. 30, n. 1, p. 110-114, 2000.

HASUI, Y. A grande Colisão Pré-Cambriana do Sudeste brasileiro e a Estruturação Regional. São Paulo, UNESP, Geociências, v. 29, n. 2, p. 141-169, 2010.

HASUI, Y. Sistema Orogênico Mantiqueira. In: HASUI, Y., CARNEIRO, C.D.R., ALMEIDA, F.F.M.A., BARTORELLI, A. (org.) Geologia do Brasil. São Paulo, Beca, p. 331-372, 2012.

HASUI, Y. \& OLIVEIRA, M.A.F. Província Mantiqueira. Setor Central. In: ALMEIDA, F. F. DE \& HASUI, Y. (Eds). O Pré-cambriano do Brasil. São Paulo, p. 308-344, 1984.

HASUI, Y.; CARNEIRO, C.D.R.; BISTRICHI, C.A. Os Granitos e Granitóides da Região de Dobramentos Sudeste nos Estados de São Paulo e Paraná. In: CONGRESSO BRASILEIRO DE GEOLOGIA, 30, Recife. Anais... Recife: SBG, p. 2579-2593, 1978

HEILBRON, M.; PEDROSA-SOARES, A.C.; CAMPOS NETO, M.C.; SILVA, L.. TROUW, R.A.J.; JANASI, V. A Província Mantiqueira. In: MANTESSO NETO, V., BARTORELLI, A., CARNEIRO, C.D.R., BRITO-NEVES, B.B. (Eds.) 2004. Geologia do Continente Sul-americano. São Paulo: Ed. Beca, p. 203-236, 2004.

KOPS, P.T. Geologia das Formações Antinha, Votuverava e Água Clara à sudeste do Complexo Granítico Três Córregos, Estado do Paraná. Rio Claro, 1994. 132 p. Dissertação (Mestrado)- Instituto de Geociências, Universidade Estadual Paulista.

MARINI, O.J.; TREIN, E.; FUCK, R.A. O Grupo Açungui no Estado do Paraná. Boletim Paranaense de Geociências, v. 23/25, p. 43-103, 1967.

PERROTTA, M.M. Potencial aurífero de uma região do Vale do Ribeira, São Paulo, estimado por modelagem de dados geológicos, geoquímicos e geofísicos num sistema de informações georreferenciadas. São Paulo, 1996. Tese (Doutorado) - Instituto de Geociências, Universidade de São Paulo.

PERROTTA, M.M., SALVADOR, E.D., LOPES, R.C., D'AGOSTINHO, L. Z., PERUFFO, N., GOMES, S.D., SACHS, L.L, MEIRA, V.T., GARCIA, M.G.M., LACERDA FILHO, J.V. Mapa Geológico do Estado de São Paulo, escala 1:750.000. Programa Geologia do Brasil - PGB, CPRM, São Paulo, 2005

PETRI, S. \& SUGUIO, K. Sobre os metassedimentos do grupo Açungui do extremo sul do estado de São Paulo. São Paulo. Secretaria de Serviços e Obras Públicas/Faculdade de Filosofia, Ciências e Letras da USP, p. 1-98, 1969.

PIRES, F.A. Faciologia e análise paleoambiental da sequência deposional Furnas Lajeado (Grupo Açungui) de idade proterozoica. Revista Brasileira de Geociências, v. 21, p. 355-362, 1981.

PRAZERES FILHO, H.J.; HARARA, O.M.; BASEI, M.A.S.; PASSARELLI, C.R.; SIGA JUNIOR, O. Litoquímica, geocronologia U-Pb e geologia isotópica (Sr-Nd-Pb) das rochas graníticas dos batólitos Cunhaporanga e Três Córregos na porção sul do Cinturão Ribeira, Estado do Paraná. Boletim IG-USP/ Série Científica, São Paulo, v. 3, p. 51-70, 2003.

REIS NETO, J.M. Faixa Itaiacoca: registro de uma colisão entre dois blocos continentais no Neoproterozoico, 1994. 296 p. Tese (Doutorado). Instituto de Geociências, Universidade de São Paulo, São Paulo, 1994.

RENNE, P.R.; DECKART, K.; ERNESTO, M.; FÉRAUD, G.; PICCIRILLO, E.M. Age of the Ponta Grossa dike swarm (Brazil), and implications to Paraná flood volcanism. Earth and Planetary Science Letters, v. 144, p. 199-211, 1996.

SANTOS, T.M.B.; TASSINARI, C.C.G; FONSECA, P.E. Diachronic collision, slab break-off and long-term high thermal flux in the Brasiliano-Pan-African orogeny: Implications for the geodynamic evolution of the Mantiqueira Province. Precambrian Research, v. 260, p. 1-22, 2015. 
SIGA JUNIOR, O. Domínios tectônicos do Sudeste do Paraná e nordeste de Santa Catarina: geocronologia e evolução crustal, 1995. 212p. Tese (Doutorado), Instituto de Geociências, Universidade de São Paulo, São Paulo, 1995.

SIGA JUNIOR, O.; BASEI, M.A.S.; PASSARELLI, C.R.; SATO, K.; CURY, L.F.; MCREATH, I. Lower and Upper Neoproterozoic magmatic records in Itaiacoca Belt (ParanáBrazil):zircon ages and lithostratigraphy studies. Gondwana Research, v. 15, p. 197-208, 2009SIGA JUNIOR, O., BASEI, M.A.S., SATO, K., PASSARELLI, C.R., NUTMAN, A., MCREATH, I., PRAZERES FILHO, H.J. Calymmian (1.50-1.45 Ga) magmatic records in Votuverava and Perau sequences south-southeastern Brazil: zircon ages and $\mathrm{Nd}-\mathrm{Sr}$ isotopic geochemistry. Journal of South American Earth Sciences. v. 32, p. 301-308, 2011.

SOARES, P.C. Sequências tectonossedimentares e tectônica deformadora no centro-oeste do escudo paranaense. In: SIMPÓSIO SUL-BRASILEIRO DE GEOLOGIA, 3. Curitiba, 1987. Atas...Curitiba: SBG, v. 2, p. 743- 771, 1987.

SOARES, P.C. Tectônica colisional em torno do bloco Paraná, Brasil. In: CONGRESSO LATINO-AMERICANO DE GEOLOGIA, 7. Belém, 1988. Anais... Belém: SBG, v. 1, p. 63-79, 1988.

SOUZA, A.P. Mapa geológico na escala 1:50.000 e esboço da evolução tectônica e sedimentar do Grupo Itaiacoca nas folhas Barra do Chapéu e Ouro Verde-SP/PR. São Paulo, 1990. 200p. Dissertação (Mestrado)- Instituto de Geociências, Universidade de São Paulo.

SPINELLI, F.P. \& GOMES, C.B. A ocorrência alcalina de Cananéia, litoral Sul do Estado de São Paulo: geologia e geocronologia. Geologia USP. Série Científica, v. 8, n 2, p. 53- 64, 2008.
TAKAHASHI, A.T., FERREIRA, J.C.G., THEODOROVICZ, A. BATOLLA JUNIOR, F., CHIODI FILHO, C. Mapa Geológico da Folha Guapiara (SG.22-X-B-II-2). SUREGSP. Relatório Final, 130 p., 1984.

TASSINARI, C.C.G.; BARBOUR, A.P.; DAITX, E.C.; SATO. K. Aplicação dos isótopos de $\mathrm{Pb}$ e $\mathrm{Sr}$ na determinação da natureza das fontes das mineralizações de chumbo do Vale do Ribeira - SP e PR. In: CONGRESSO BRASILEIRO DE GEOLOGIA, 36. Natal. 1990. Anais... Natal: SBG. n. 3, p. 1254-1266, 1990

VIEIRA, O.A.R.P. Geologia da Folha Guapiara 1:50000 (SG-22-X-B-II-2). Rio Claro. 2017, 145p. Dissertação (Mestrado)- Instituto de Geociências e Ciências Exatas, Universidade Estadual Paulista.

VIEIRA, O.A.R.P., GODOY, A.M., LEITE JUNIOR, W.B., HACKSPACHER, P.C. Geologia da Folha Topográfica Guapiara na escala 1:50.000. São Paulo, UNESP, Geociências, v. 37, n. 2, p. 267-277, 2018.

WEBER, W.; SIGA JÚNIOR, O.; SATO, K.; REIS NETO, J.M.; BASEI, M.A.S.; NUTMAN, A.P. A Formação Água Clara na região de Araçaíba - SP: registro de uma bacia mesoproterozoica. Geologia USP, Série Científica, v. 4, p. 101-110, 2004. 